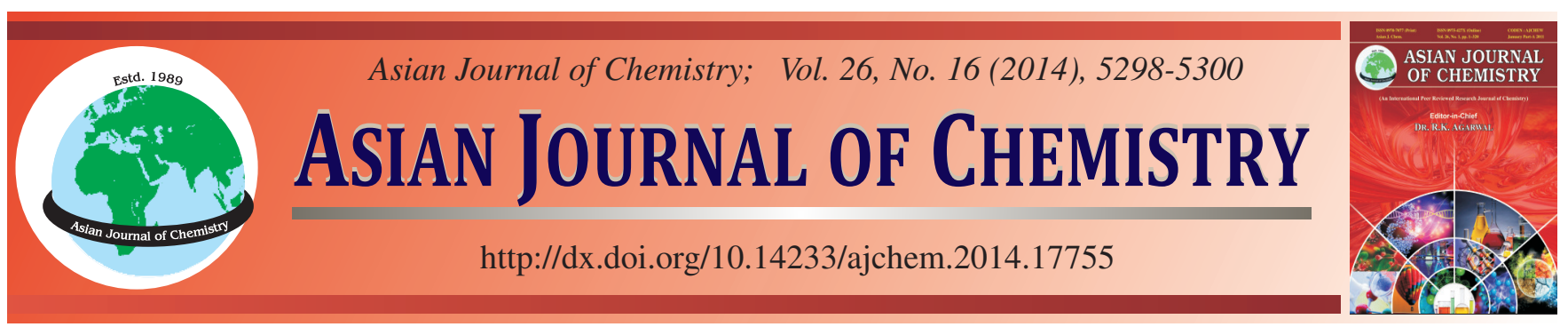

\title{
Spectroscopic Characterization of Some Oxovanadium(IV, V) Complexes
}

\author{
Reetesh Kumar ${ }^{1}$, Puja Singh ${ }^{1}$, Umesh Kumar ${ }^{1}$, S. Suman Singh $^{2}$, A.K. Saha ${ }^{2}$ and Shivadhar Sharma ${ }^{1, *}$
}

${ }^{1}$ University Department of Chemistry, Magadh University, Bodh Gaya-824 231, India

${ }^{2}$ P.G. Department of Chemistry, St. Columba's College, Hazaribagh-825 301, India

*Corresponding author: E-mail: sharma.shivadhar@gmail.com

Received: 3 April 2014;

Accepted: 15 June 2014;

Published online: 28 July 2014;

AJC-15682

Six new oxovanadium(IV, V) complexes of N-bis(caproyl)hydroxamic acid, N-caproyl acetohydroxamic acids and N-caproyl benzohydroxamic acids have been synthesized. The synthesized hydroxamic acids and their oxovanadium(IV, V) complexes were characterized by melting point, running TLC for single spot, elemental analysis, IR, ${ }^{1} \mathrm{H}$ NMR and electronic spectral studies. The spectral studies suggest distorted octahedral geometry for both $\mathrm{V}(\mathrm{IV})$ and $\mathrm{V}(\mathrm{V})$ metal complexes.

Keywords: Oxovanadium(IV, V), Distorted octahedral.

\section{INTRODUCTION}

In the current decade considerable interest has been focused on the hydroxamic acids, which has been known to possess a broad spectrum of biological activities such as antibacterial, antifungal ${ }^{1}$, antibiotics ${ }^{2}$, anticancer ${ }^{3}$ and antioxidant ${ }^{4}$. They are also acquiring much significance as analytical reagents for solvent extraction ${ }^{5}$, liquid-liquid extraction ${ }^{6}$, froth flotation $^{7}$, stabilizers of photographic developing solutions ${ }^{8}$ and spectrophotometer titrations of several metal ions 9 . The biological importance of the vanadium on a triple level, nutritional, pharmacological and toxicological effects are determined by performing a large scale investigation of medicinal plants about their vanadium content and evaluation of the extraction ratio of this element on the herbal teas ${ }^{10}$. The no. of patients with diabetes mellitus (DM) is fastly increasing and it was approximately 250 million worldwide in the last decade ${ }^{11}$. Diabetes mellitus is a disease that results in the chronic hyperglycemia due to an absolute or partial lack of insulin which in turn impairs the glucose, protein and lipid metabolism and ultimately causes several secondary complication ${ }^{12}$. Insulin is a signaling hormone which is essential for the metabolism of both carbohydrate and fat. The increased insulin level normally promotes glucose uptake by the liver, gut and peripheral tissues that results in energy production and storage as required by the organism ${ }^{13}$. During the past two decades Se, $\mathrm{Cr}, \mathrm{Mn}, \mathrm{Mo}, \mathrm{W}, \mathrm{V}$ and $\mathrm{Zn}$ ions have been reported to show insulin like effects ${ }^{14,15}$. Vadanium compounds however, have been proved to be one of the most efficient. A good number of vanadium $(\mathrm{IV}, \mathrm{V})$ complexes have been prepared and tested for antidiabetic agents ${ }^{16}$. These facts have prompted us to synthesize new hydroxamic acids and their vanadium(IV, V) metal complexes, which is an extension of our previously reported work $^{17,18}$.

\section{EXPERIMENTAL}

Synthesis of N-bis(caproyl)hydroxamic acid (NBCHA): Finely powdered hydroxylamine hydrochloride [0.694 g, 0.01 mol] dissolved in $15 \mathrm{~mL}$ distilled water was mixed with $10 \mathrm{~mL}$ aqueous solution of $[0.40 \mathrm{~g}, 0.01 \mathrm{M}]$ sodium hydroxide. This mixture was stirred by a mechanical stirrer at $0{ }^{\circ} \mathrm{C}$ using external freezing. Then, ethereal solution of $[2.75 \mathrm{~mL}, 0.02$ mol] caproyl chloride was added slowly to the above solution for $1.5 \mathrm{~h}$ with constant stirring until precipitate was obtained. The obtained crude product was again dissolved in methanol, filtered and dried over anhydrous $\mathrm{CaCl}_{2}$ under reduced pressure in vacuum desiccators. Similarly, N-caproyl acetohydroxamic acid (NCAHA) and N-caproyl benzohydroxamic acid (NCBHA) were also synthesized by adding 1:1 molar ratio of caproyl chloride and benzoyl/acetyl chloride respectively.

\section{Synthesis of metal complexes}

Synthesis of vanadium(IV) metal complexes: $0.005 \mathrm{~mol}$ NBCHA/NCAHA/NCBHA were dissolved in $20 \mathrm{~mL}$ deionized water and then nitrogen gas was bubbled through this solution for $15 \mathrm{~min}$ with constant stirring. Then, $0.0025 \mathrm{~mol}$ vanadyl sulphate dissolved in $15 \mathrm{~mL}$ deionized water was added and allowed to react for 45-60 min with the nitrogen gas bubbling at room temperature. Coloured solid products 
were obtained which were dried at room temperature and finally in a desiccator over anhydrous $\mathrm{CaCl}_{2}$.

Synthesis of vanadium(V) metal complexes: $0.005 \mathrm{~mol}$ NBCHA/NCAHA/NCBHA were dissolved in $20 \mathrm{~mL}$ deionized water and then nitrogen gas was bubbled through this solution for $15 \mathrm{~min}$ with constant stirring. Then, $0.0025 \mathrm{~mol}$ ammonium metavanadate dissolved in $15 \mathrm{~mL}$ concentrated $\mathrm{HCl}$ was added and allowed to react for 45-60 min with the nitrogen gas bubbling at room temperature. Coloured solid products were obtained which were dried at room temperature and finally in a desiccator over anhydrous $\mathrm{CaCl}_{2}$.

Physical and analytical measurements: The hydroxamic acids and their metal complexes were analyzed for $\mathrm{C}, \mathrm{H}$ and $\mathrm{N}$ by using micro analyzer technique on Thomas $\mathrm{CH}$-analyzer35-Carlo Erba-1106 and Coleman-N-analyzer at CDRI Lucknow. IR spectra were recorded in the range of 4000-400 $\mathrm{cm}^{-1}$ Perkin Elmer spectrophotometer model Rx1 using $\mathrm{KBr}$ pellets. ${ }^{1} \mathrm{H}$ NMR spectra were recorded on NMR spectrometer Bruker DRX-300 (300 MHz FT-NMR with low and high temperature facility $-90^{\circ} \mathrm{C}$ to $+80^{\circ} \mathrm{C}$ ) at SAIF, CDRI, Lucknow. Electronic spectra were recorded on UV 6000 spectrophotometer at SAIF, Chandigarh.

\section{RESULTS AND DISCUSSION}

Physical and analytical data of hydroxamic acids and their vanadium metal $(\mathrm{IV}, \mathrm{V})$ complexes are presented in Table-1. All the complexes were found coloured and stable at room temperature. In the IR spectra of hydroxamic acids an absorption peak in the region $3468-3417 \mathrm{~cm}^{-1}$ is appeared which may be attributed to $\mathrm{N}-\mathrm{OH}$ stretching vibration. This band has disappeared in the IR spectra of metal complexes indicating the coordination of the ligand to the metal ion through hydroxyl group via deprotonation ${ }^{19}$. An absorption band in the region $2957-2841 \mathrm{~cm}^{-1}$ appears in the IR spectra of hydroxamic acids and their metal complexes which may be attributed to the $\mathrm{C}-\mathrm{H}$ stretching vibrations of polymethylene linkage. The carbonyl stretching vibration observed in the region $1688-1675 \mathrm{~cm}^{-1}$ in the IR spectra of hydroxamic acids ${ }^{20-22}$. This band has shifted towards lower region by $40-30 \mathrm{~cm}^{-1}$ in the case of metal complexes which clearly indicates the co-ordination of the ligands to the metal ion through oxygen atom of carbonyl group. In the infrared spectra of hydroxamic acids and their metal complexes an absorption band in the region 1372-1315 $\mathrm{cm}^{-1}$ appears which may be attributed to $\mathrm{C}-\mathrm{N}$ stretching vibrations $^{23-25}$. A medium sharp intensity band in the region $1160-1114 \mathrm{~cm}^{-1}$ is observed in the infra-red spectra of hydroxamic acids and their metal complexes which may be attributed due to stretching vibrations of -N-O group ${ }^{26-30}$. In the IR spectra of vanadium(IV) metal complexes a medium sharp intensity band in the region $969-985 \mathrm{~cm}^{-1}$ is obtained which may be attributed due to $\mathrm{V}=\mathrm{O}$ stretching vibrations whereas in the IR spectra of vanadium $(\mathrm{V})$ metal complexes a band in the region 963.2-941.4 $\mathrm{cm}^{-1}$ has appeared which may be due to $\mathrm{VOCl}$ stretching vibrations ${ }^{31-33}$. Two bands in the region 3479- 3405 $\mathrm{cm}^{-1}$ and $922-809 \mathrm{~cm}^{-1}$ are observed in the infrared spectra of all metal complexes which indicate the presence of coordinated water molecule in the co-ordination sphere. All complexes exhibited a new band in the region $470-460 \mathrm{~cm}^{-1}$ which may be attributed due to the formation of $\mathrm{V}-\mathrm{O}$ bonds $\mathrm{b}^{34,35}$. Appearance of this band further confirms the coordination of carbonyl group and oxygen of hydroxyl group via deprotonation of ligand with the metal ions.

The synthesized hydroxamic acids exhibited a singlet in the range of $\delta 10.339-10.889 \mathrm{ppm}$ due to $\mathrm{NOH}$ proton. Ligand NBCHA exhibited two triplet one in the range $\delta 0.818-0.862$ ppm due to $-\mathrm{CH}_{3}$ protons of $-\mathrm{CH}_{2} \mathrm{CH}_{3}$ moiety and other in the range $\delta$ 2.978-3.203 ppm due to $\mathrm{COCH}_{2}$ protons. Two multiplets appeared, one in the range $\delta 1.361-1.512 \mathrm{ppm}$ due to polymethylene protons and second in the range $\delta 1.873-2.019$ ppm due to two protons of $-\mathrm{CH}_{2}-$ of $-\mathrm{CH}_{2} \mathrm{CH}_{3}$ moiety. Ligand NCAHA has shown singlet at $\delta 3.410 \mathrm{ppm}$ due to three protons of $\mathrm{CH}_{3}$ of $-\mathrm{COCH}_{3}$ moiety. Two triplet appear one in the range

TABLE-1

PHYSICAL PROPERTIES AND PERCENTAGE COMPOSITION OF SYNTHESIZED HYDROXAMIC ACIDS AND THEIR METAL COMPLEXES

\begin{tabular}{|c|c|c|c|c|c|c|c|c|c|}
\hline \multirow{2}{*}{ Compound } & \multirow{2}{*}{ m.f. } & \multirow{2}{*}{ Colour } & \multicolumn{6}{|c|}{ Elemental analysis (\%): Found (Calcd.) } & \multirow{2}{*}{$\begin{array}{l}\text { m.p./decompo- } \\
\text { sition temp. } \\
\left( \pm 2{ }^{\circ} \mathrm{C}\right)\end{array}$} \\
\hline & & & M & $\mathrm{C}$ & $\mathrm{H}$ & $\mathrm{N}$ & $\mathrm{S}$ & $\mathrm{Cl}$ & \\
\hline NBCHA & $\mathrm{C}_{12} \mathrm{H}_{23} \mathrm{NO}_{3}$ & Brown & - & $\begin{array}{c}62.88 \\
(63.00)\end{array}$ & $\begin{array}{l}10.04 \\
(9.87)\end{array}$ & $\begin{array}{c}6.11 \\
(6.00)\end{array}$ & - & - & 120 \\
\hline NCAHA & $\mathrm{C}_{8} \mathrm{H}_{15} \mathrm{NO}_{3}$ & Creamish & - & $\begin{array}{c}55.49 \\
(55.61)\end{array}$ & $\begin{array}{l}8.67 \\
(8.42)\end{array}$ & $\begin{array}{l}8.09 \\
(7.87)\end{array}$ & - & - & 115 \\
\hline NCBHA & $\mathrm{C}_{13} \mathrm{H}_{17} \mathrm{NO}_{3}$ & Light brown & - & $\begin{array}{l}66.38 \\
(66.42)\end{array}$ & $\begin{array}{l}7.23 \\
(7.11)\end{array}$ & $\begin{array}{c}6.38 \\
(6.14)\end{array}$ & - & - & 120 \\
\hline [V(IV)NBCHA] & {$\left[\mathrm{V}(\mathrm{IV}) \mathrm{O}\left(\mathrm{C}_{12} \mathrm{H}_{22} \mathrm{NO}_{3}\right)_{2} \cdot \mathrm{H}_{2} \mathrm{O}\right] \mathrm{SO}_{4}$} & $\begin{array}{l}\text { Dark purple } \\
\text { black }\end{array}$ & $\begin{array}{c}8.01 \\
(7.88)\end{array}$ & $\begin{array}{c}45.21 \\
(45.46)\end{array}$ & $\begin{array}{c}7.22 \\
(7.00)\end{array}$ & $\begin{array}{c}4.39 \\
(4.12)\end{array}$ & $\begin{array}{c}5.02 \\
(4.88)\end{array}$ & - & 118 \\
\hline [V(IV)NCAHA] & {$\left[\mathrm{V}(\mathrm{IV}) \mathrm{O}\left(\mathrm{C}_{8} \mathrm{H}_{14} \mathrm{NO}_{3}\right)_{2} \cdot \mathrm{H}_{2} \mathrm{O}\right] \mathrm{SO}_{4}$} & Purple black & $\begin{array}{c}9.71 \\
(9.50)\end{array}$ & $\begin{array}{l}36.57 \\
(36.63)\end{array}$ & $\begin{array}{l}5.71 \\
(5.53)\end{array}$ & $\begin{array}{l}5.33 \\
(5.14)\end{array}$ & $\begin{array}{c}6.01 \\
(5.91)\end{array}$ & - & 120 \\
\hline [V(IV)NCBHA] & {$\left[\mathrm{V}(\mathrm{IV}) \mathrm{O}\left(\mathrm{C}_{13} \mathrm{H}_{16} \mathrm{NO}_{3}\right)_{2} \cdot \mathrm{H}_{2} \mathrm{O}\right] \mathrm{SO}_{4}$} & $\begin{array}{l}\text { Dark purple } \\
\text { black }\end{array}$ & $\begin{array}{c}7.86 \\
(7.62)\end{array}$ & $\begin{array}{l}48.07 \\
(48.44)\end{array}$ & $\begin{array}{c}5.24 \\
(5.10)\end{array}$ & $\begin{array}{c}4.31 \\
(4.18)\end{array}$ & $\begin{array}{c}4.93 \\
(4.76)\end{array}$ & - & 120 \\
\hline [V(V)NBCHA] & {$\left[\mathrm{V}(\mathrm{V}) \mathrm{OCl}\left(\mathrm{C}_{12} \mathrm{H}_{22} \mathrm{NO}_{3}\right)_{2} \cdot \mathrm{H}_{2} \mathrm{O}\right] \mathrm{Cl}_{2}$} & $\begin{array}{l}\text { Dark purple } \\
\text { black }\end{array}$ & $\begin{array}{c}7.88 \\
(7.71)\end{array}$ & $\begin{array}{c}44.48 \\
(44.59)\end{array}$ & $\begin{array}{l}7.10 \\
(6.94)\end{array}$ & $\begin{array}{c}4.32 \\
(4.11)\end{array}$ & - & $\begin{array}{l}10.96 \\
(10.87)\end{array}$ & 118 \\
\hline [V(V)NCAHA] & {$\left[\mathrm{V}(\mathrm{V}) \mathrm{OCl}\left(\mathrm{C}_{8} \mathrm{H}_{14} \mathrm{NO}_{3}\right)_{2} \cdot \mathrm{H}_{2} \mathrm{O}\right] \mathrm{Cl}_{2}$} & Purple black & $\begin{array}{c}9.52 \\
(9.27)\end{array}$ & $\begin{array}{l}35.85 \\
(35.97)\end{array}$ & $\begin{array}{l}5.60 \\
(5.48)\end{array}$ & $\begin{array}{l}5.23 \\
(4.97)\end{array}$ & - & $\begin{array}{l}13.26 \\
(13.00)\end{array}$ & 118 \\
\hline [V(V)NCBHA] & {$\left[\mathrm{V}(\mathrm{V}) \mathrm{OCl}\left(\mathrm{C}_{13} \mathrm{H}_{16} \mathrm{NO}_{3}\right)_{2} \cdot \mathrm{H}_{2} \mathrm{O}\right] \mathrm{Cl}_{2}$} & $\begin{array}{l}\text { Dark purple } \\
\text { black }\end{array}$ & $\begin{array}{l}7.73 \\
(7.57)\end{array}$ & $\begin{array}{c}47.30 \\
(47.59)\end{array}$ & $\begin{array}{l}5.15 \\
(5.01)\end{array}$ & $\begin{array}{c}4.25 \\
(4.13)\end{array}$ & - & $\begin{array}{l}10.76 \\
(10.63)\end{array}$ & 120 \\
\hline
\end{tabular}

NBCHA = N-bis(caproyl)hydroxamic acid; NCAHA = N-caproyl acetohydroxamic acid; NCBHA = N-caproyl benzohydroxamic acid 
$\delta$ 0.826-0.851 ppm due to $\mathrm{CH}_{3}$ protons of $-\mathrm{CH}_{2} \mathrm{CH}_{3}$ moiety and second appeared in the range $\delta 2.981-3.206 \mathrm{ppm}$ due to $-\mathrm{COCH}_{2}$ protons. Two multiplets appeared one in the range $\delta$ 1.228-1.517 ppm due to polymethylene protons and second in the range $\delta 1.877-2.021 \mathrm{ppm}$ due to $-\mathrm{COCH}_{2}$ protons. Ligand NCBHA exihibited one multiplet in the range $\delta 1.914-2.050$ ppm due to polymethylene protons. The another multiplets appeared in the range 3.031-3.166 ppm due to $-\mathrm{CH}_{2}$ protons of polymethylene linkage and multiplets due to aromatic protons in the range $\delta 7.411-7.503 \mathrm{ppm}$. Two triplets one appeared at $\delta 1.914-1.962 \mathrm{ppm}$ due to $-\mathrm{CH}_{3}$ protons and second appears at $\delta$ 2.668-2.716 ppm due to $\mathrm{COCH}_{2}$ protons.

The electronic spectra of vanadium(IV) complexes exhibited three bands in the region $13440-12940 \mathrm{~cm}^{-1}, 16550$ $16129 \mathrm{~cm}^{-1}, 24650-23150 \mathrm{~cm}^{-1}$ corresponding to the transitions ${ }^{2} \mathrm{~B}_{2 \mathrm{~g}} \rightarrow{ }^{2} \mathrm{E}_{\mathrm{g}},{ }^{2} \mathrm{~B}_{2 \mathrm{~g}} \rightarrow{ }^{2} \mathrm{~B}_{1 \mathrm{~g}},{ }^{2} \mathrm{~B}_{2 \mathrm{~g}} \rightarrow{ }^{2} \mathrm{~A}_{1 \mathrm{~g}}$ respectively which suggest distorted octahedral geometry ${ }^{36}$ for these complexes. However, as expected the vanadium(V) complexes do not show significant bands in their electronic spectra due to diamagnetic nature of vanadium(V).

On the basis of elemental analysis and spectral studies, it is suggested that all the $\mathrm{V}(\mathrm{IV})$ and $\mathrm{V}(\mathrm{V})$ metal complexes of hydroxamic acids have distorted octahedral geometry as presented in the Figs. 1 and 2.

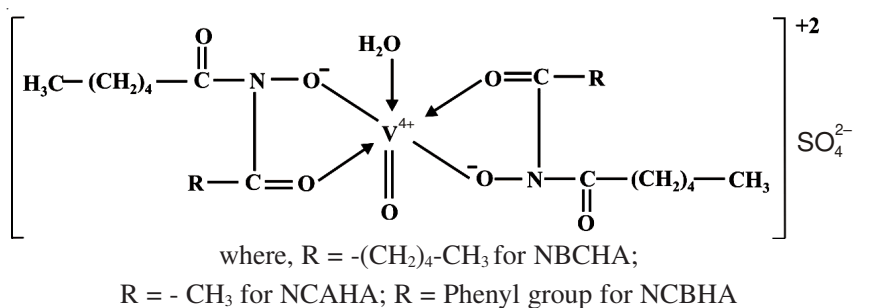

Fig. 1. Vanadium(IV) metal complexes of hydroxamic acids

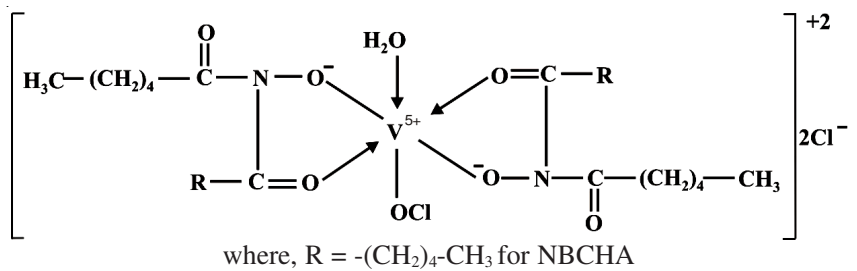

$\mathrm{R}=-\mathrm{CH}_{3}$ for NCAHA; $\mathrm{R}=$ Phenyl group for NCBHA

Fig. 2. Vanadium(V) metal complexes of hydroxamic acids

\section{REFERENCES}

1. A. Isha, N.A. Yusof, M. Ahmad, D. Suhendra, W.M.Z.W. Yunus and Z. Zainal, Spectrochim. Acta, 67, 1398 (2007).

2. W.H. Hoidy, M.B. Ahmad, E.A.J. Al-Mulla, W.M.Z.W. Yunus and N.B. Ibrahim, J. Oleo Sci., 59, 15 (2010).

3. L.P. Tardibono and M.J. Miller, Org. Lett., 7, 1575 (2009).

4. M. Koncic, Z. Rajic, N. Petric and B. Zorc, Acta Pharm., 59, 235 (2009).

5. Y.K. Agrawal, G. Shah and S.B. Vora, J. Radioanal. Nucl. Chem., 270, 453 (2006).

6. Y.K. Agarwal and C. R. Sharma, Indian J. Chem., 46A, 1772 (2007).

7. S.I. Gorlovskii and Obroz Tsky Tovorang, Zauki, 38, 16 (1981).

8. V.K. Agarwal and A.J. Midair, J. Indian Chem. Soc., 34, 757 (1977).

9. H.R. Das and S.C. Shome, Anal. Chim. Acta, 35, 256 (1966).

10. D.S. Antal, C.A. Dehelean, C.M. Canciu and M. Anke, J. Anaiele Univ. din Oradea Fascicula Biol., 2, 5 (2009).

11. T. Kiss, T. Jakusch, D. Hollender, A. Dörnyei, E.A. Enyedy, J.C. Pessoa, H. Sakurai and A. Sanz-Medel, Coord. Chem. Rev., 252, 1153 (2008).

12. M.A. Atkinson and N.K. Maclaren, Sci. Am., 260, 42 (1990).

13. K.H. Thompson, J.H. McNeill and C. Orvig, Chem. Rev., 99, 2561 (1999).

14. K.H. Thompson, J. Chiles, V.G. Yuen, J. Tse, J.H. McNeill and C. Orvig, J. Inorg. Biochem., 98, 683 (2004).

15. H. Sakurai, Y. Kojima, Y. Yoshikawa, K. Kawabe and H. Yasui, Coord. Chem. Rev., 226, 187 (2002).

16. K.H. Thompson and C. Orvig, J. Inorg. Biochem., 100, 1925 (2006).

17. S. Sharma, M. Kumar and T. Sharma, J. Indian Chem. Soc., 52, 761 (1985).

18. R. Ranjan, R. Rani, V. Kumar, A.K. Singh Jr. and S. Sharma, J. Indian Chem. Soc., 85, 317 (2008)

19. J. Fugita, K. Nakamoto and M. Kooayashi, J. Am. Chem. Soc., 78, 3968 (1956).

20. E. Wafa, M. Abu and E.I.M. Deekin, Indian J. Chem., 29A, 285 (1990).

21. F. Mathis, Bull. Soc. Chem., D-9, 22 (1953).

22. F.J. Fasha, M.S. Thesis, Wichita State University, Wichita Kansas (1957).

23. E.M. Vsova and E.M. Voroshin, Dok-1 Akasd Nauk SSSR., 113, 1306 (1957).

24. L.J. Bellamy, The Infra-red Spectra of Complex Molecules, John Wiley \& Sons. Inc., New York (1958).

25. A. Palm and H. Werbin, Can. J. Chem., 31, 1004 (1953).

26. G. Allen, P.S. Ellington and G.D. Meakins, J. Chem. Soc., 1909 (1960).

27. S. Pinchas and I. Lavtichat, Infra-red Spectra of Labelled Compounds, Academic Press, New York (1971).

28. P.A. Giguère and I.D. Liu, Can. J. Chem., 30, 948 (1952).

29. A.K. Banerjee and P. Dharmprakash, J. Indian Chem. Soc., 55, 755 (1978).

30. J.F. Brown, J. Am. Chem. Soc., 77, 6341 (1955).

31. B. Singh, B.P. Yadav and R.C. Agarwal, Indian Chem., 23A, 332 (1984).

32. M. Kumar, A. Choudhary and S. Sharma, Indian J. Chem., 25A, 281 (1986).

33. T. Ghosh, J. Indian Chem. Soc., 81, 957 (2004).

34. M.M. Patel, M.R. Patel and B.N. Mankad, J. Indian Chem. Soc., 54, 1188 (1977).

35. F.F. Bentley, L.D. Somothsen and A.L. Rojek, Infra-red Spectra and Characteristic Frequencies 700-300 $\mathrm{cm}^{-1}$, Interscience Publisher, London (1968).

36. W.J. Geary, Coord. Chem. Rev., 7, 81 (1971). 